\title{
A Comparative Analysis between English and Indonesian Phonological Systems
}

\author{
Baso Andi-Pallawa \\ Department of English language and Teaching \\ Faculty of Teachers Training and Educational Sciences \\ Tadulako University, Palu, Middle Sulawesi, East Indonesia, January, 2007 \\ Tel: 620-813-3396-9613Ｅ-mail: andipallawab@rocketmail.com \\ Dr. Andi Fiptar Abdi Alam (Corresponding author) \\ Faculty of Education of Tadulako University \\ Kampus Bumi Tadulako Tondo Tlp. 429743, Centre: 246,247,249,250 \\ Palu City, Middle Sulawesi Province, East Indonesia
}

Received: May 15, 2013 Accepted: June 22, 2013 Published: June 23, 2013

doi:10.5296/ijele.v1i3.3892 URL: http://dx.doi.org/10.5296/ijele.v1i3.3892

\begin{abstract}
This research deals with the descriptions and analyses on phonological systems of English and Indonesian languages which supply several similarities and differences. Similarities do not make the seventh semester students of the English Department of Tadulako University have trouble in learning L2 (English), but the differences between two languages do. Therefore, the parallels are not the problematic cases in the learning of L2 phonological system anyway. Based on the collected data, some differences are discovered such as phonemic oppositions and phonetic features, and so are their similarities. The approach applied in this study was qualitative. The data were collected via observation, interviews, and recording which were constructed in the form of field-notes. This study involved 20 English students of the English Department of Tadulako University. They have already had experiences in learning English but they still have problems in pronouncing English words.
\end{abstract}

Keywords: contrastive analyses, phonology, phonemes, phonemic systems, phonemic oppositions, and phonetic features 


\section{Introduction}

To investigate a language we usually start with 'utterances.' An utterance thus defined can be as short as a single word or as long as a speech/oration. Utterances can convey an almost infinite number of meanings and combinations of meanings, yet all the meanings communicated via language in any utterance are sent out through a limited number of different sounds (written symbols).

With respect to the above statement, Goldsmith, (1995) states broadly that each language is a structurally different system. When two languages are compared from the point of view of their structure and organization, it is recognized that the marvelous variety of the languages of mankind indicates astonishing similarities. Both languages possess phonemes, morphemes, words, sentences and clear sentence varieties, definite parts of speech, systems, meanings, etc.

To acknowledge accurately that each language is a structurally distinctive system of communication, at least two languages are analyzed to find out their contrast. Therefore, this study concentrates the analyses on 'comparative analyses of the English and Indonesian phonological systems' in terms of the different features of each phoneme. The comparative analyses of the phonological procedures either in L1 (the Indonesian language) or in L2 (the English language) should investigated how they differ respectively to seek the differences that might hamper the students in learning L2. The more dissimilarity that can be discovered, the more problems can be overcome as difficulties caused by the discrepancies between L1 and L2. In short, all phonemes that appear in English are analyzed and compared with Indonesian phonemes what the English phonemes do not occur in the Indonesian phonological systems.

\section{Literature Review}

The following are the definitions of phonology, phonetic, phonemic, and phonotactic, presented respectively. The definitions deal with what phonology, phonetic and phoneme are. Phonology is a subfield of linguistics which studies the sound system of a specific language or set of languages. Phonology describes the way sounds function within a given language or across languages, whilst, phonetics is about the physical production and perception of the speech sounds (Roach, 2000). Further, phoneme is the smallest meaningful unit of sound in a language. A meaningful sound is one that will change one word into another word. For example, the words cat and fat are two different words, but there is only one sound that is different between the two words - the first sound. That means that the " $\mathrm{k}$ " sound in cat and the ' $\mathrm{f}$ ' sound in fat are two different morphemes (Gimson, 1980).

Second definitions refer to what phonemic and phonotactic are. Roach (2000) states that phonemic is the study of the sound system of a given language and the analysis and classification of its phonemes, while phonotactic is the study of the possible sound arrangements of words of that language.

With respect to the above definitions, it can be commented that phonological systems play a major role in learning to read words, sentences or paragraphs in a particular language. They 
refer to the sound of one's language in the processing of reading and speaking. Successful acquisition of phonological representations needs accurate perception of phonemic. It is proved empirically that phonological systems help in the development of fine reading and speaking.

In addition, teaching English sounds to Indonesian students creates many problems, one of which is the constant interference of the native language systems of the students on that of the target language. Being able to recognize the problems that make Indonesian students fail to communicate fluently, the contrastive analysis can be used to find out the differences and similarities between English and Indonesian phonemes.

Goldsmith (1995) ever states that many language teachers still find contrastive analysis (CA) useful, especially in phonology. Transfer is present in phonology more than any other area and it is because of this fact that one can guess the first language of a speaker through his/her accent while speaking or reading a second language. Indonesian scholars of language have tried to compare and contrast various aspects of the Indonesian language (Bahasa Indonesia) with those of English. These include brief contrastive analysis (CA) outlines to comprehensive analyses. Dardjowidjojo (1978) tries to explain pronunciation problems of Indonesian students learning English. Since the source of problems lies in the differences between the two languages, exercises based on a careful contrastive analysis are the best for the teaching of pronunciation, and for the findings of the discrepancies and similarities.

Furthermore, Brown (2000) claims that the principle barrier to second language acquisition is the interference of the first language system with the second language system, and that a scientific, structural analysis of the two languages in questions would yield a taxonomy of linguistic contrasts between them which in turn would enable the linguist to predict the difficulties a learner would encounter. Whilst, Storkel, (2003) confirms that since the learner tends to transfer the habits of his native language structure to the foreign language, we have here the major source of difficulty or ease in learning the structure of a foreign language. Those structures that are similar will be easy to learn because they will be transferred and may function satisfactorily in the foreign language. Those structures that are different will be difficult because when transferred they will not function satisfactorily in the foreign language and will therefore have to be changed.

Based on the above quotations, the researcher of this study wishes to find out the major differences between the phonological systems of English and those of Indonesian in the hope that he will be able to solve the handicaps that create troubles or difficulties to the Indonesian students of the English Department.

\section{Research Methods}

The design of this study is a descriptive qualitative. It is qualitative in nature, trying to explain and describe and analyze data, which are displayed in the form of field-notes. The findings of this study are revealed not by tools of statistical procedures or other devices of quantification. Based on this feature, this study is named "qualitative research because its main method of data collection is tightly related to observation, interviews, and recording. 


\section{Ml Macrothink}

This project was carried out at the Faculty of Education of Tadulako University by involving 20 students of the seventh semester of the English Department. The 20 students have already passed pronunciation practice I and II. It means, they have already been taught the phonological systems of English. However, those students still have problems of the phonological system of English. This case induces the researcher to conduct study why the students face troubles to pronounce the English words or sentences correctly, and what make them get problems in speaking English.

\subsection{Data Collection Procedures}

To obtain accurate data, the 20 students were assigned to read an English text in a queue. When each of the 20 students was reading, her/his utterances were recorded by a set of a mini tape-recorder. After that the 20 students were also requested to present a short speech orally in a queue in other meetings (Based on the schedule of investigation). In essence, each English word or sentence articulated by the students in these certain activities was recorded, and noted in the field-notes.

\section{Findings and Discussion}

The descriptions and analyses of the findings are directed to answer the research questions: (1) What problems do students face when pronouncing English words/sentences? and (2) Why do students undergo difficulties when pronouncing English words/sentences?

In line with the research problems, the following are the answers of the queries above. Based on the findings, it has been found that the 20 students are not so familiar with several phonological systems of English which affect them to speak English. These obstacles are concerned with phonemic, phonetic, phonotactic discrepancies between the students' own language (the Indonesian language = Bahasa Indonesia) and the L2 language (the English language). The following findings deal with:

\subsection{Phonemic and Phonetic Differences}

Regarding to the findings of the study, it is acknowledged that most of the 20 students involved in this study face difficulties in pronouncing consonant phonemes: $/ \mathrm{b} /, / \mathrm{p} /, / \mathrm{t} /$,

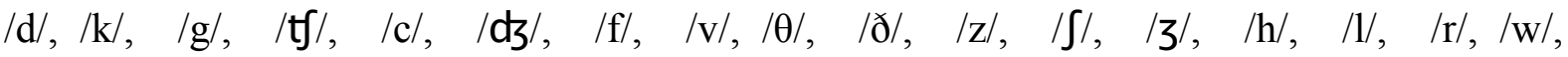
$/ \mathrm{m} /, \quad / \mathrm{n} /, / \mathrm{y} /$

The above consonant phonemes are analyzed via phonemic oppositions and phonetic features respectively as follows.

\subsubsection{Phoneme / p / in English}

The / p / in English appears in word initial, medial and final positions, and so does the /p/ in the Indonesian language (= Bahasa Indonesia). It is very essential to describe here that the English /p/ is aspirated when it happens in the initial position in a stress syllable, but when it arises after 's', it is not aspirated. It is a little aspirated when it appears in the middle and final positions, but the Indonesian phoneme /p/ is entirely not aspirated wherever it exists in the 
word. The phoneme / p / in Bahasa Indonesia is constantly unreleased when it occurs in the final position before a pause or another consonant. Consequently, the aforementioned students of this study have difficulties in pronouncing the English words having the phoneme $/ \mathrm{p} /$ with aspiration. The following are the examples discovered in the study:

\section{PHONEMIC OPPOSITIONS}

\section{ENGLISH}

Initial : 'past' $\left[p^{\text {ha }} \mathrm{a}: \mathrm{st}\right]$

Medial

$$
\text { : 'compass' }\left[\mathrm{k}^{\mathrm{h}} \Lambda \mathrm{mpos}\right]
$$

Final : 'map' [mæp]

\section{BAHASA INDONESIA}

'pagi' [pag $\mathrm{I}]=$ morning

'kapan’ [kapan] $=$ when

'kerlap' [kərlap] $=$ glare

\section{PHONETIC FEATURES}

\section{ENGLISH}

Voiced

Bilabial

Stop

Aspirated

\section{BAHASA INDONESIA}

$\begin{array}{ll}- & - \\ + & + \\ + & + \\ + & -\end{array}$

\subsubsection{Phoneme / b / in English}

The / b / phoneme in English also makes the previous students mentioned get troubles in pronouncing English words. To know the causes, the analysis of this phoneme is carried out as follows. The / b / phoneme in English appears in word initial, medial and final positions but the / b / phoneme in Bahasa Indonesia comes out only in syllable-initial position. It is a fact that a few words end in the letter ' $b$ ' in writing of Bahasa Indonesia, and when this happens, the letter ' $b$ ' is pronounced by most speakers of Bahasa Indonesia as a / $p /$. The speakers of Bahasa Indonesia do so because they might be affected by their own local languages, or probably because of the loan words from Arabic, Portuguese, etc. The following are their analyses presented below.

\section{PHONETIC FEATURES}

\section{ENGLISH}

$\begin{array}{ll}\text { Voiced } & : \\ \text { Bilabial } & : \\ \text { Stop } & :\end{array}$

\section{BAHASA INDONESIA}

$\begin{array}{ll}+ & + \\ + & + \\ + & +\end{array}$

\subsubsection{Phoneme / t / in English}

The / $\mathrm{t} /$ phoneme in English and in Bahasa Indonesia appears in the three positions in the word. When the English / $\mathrm{t}$ /appears initially in an accented syllable, it is fortis and usually accompanied by aspiration. In other positions, i.e. preceding a vowel in an unaccented syllable and finally, such aspiration as may come out is relatively weak. When the English / $t$ / follows an initial / s /, however, it is released with no aspiration even when being stressed. 


\section{Macrothink

The English / $\mathrm{t}$ / is alveolar but the Indonesian / $\mathrm{t}$ / is an apico dental. When the Indonesian / $\mathrm{t}$ / arises finally in the syllable before a pause or another consonant, it is usually unreleased. Consequently, it is slightly difficult for the aforementioned students to pronounce $/ \mathrm{t} / \mathrm{when}$ this phoneme emerges in English words with aspiration. So to pronounce this sound of $/ \mathrm{t} /$, they tend to use the unaspirated dental / $\underline{\mathrm{t}} /$. Here their analyses are presented below.

\section{ENGLISH}

Initial : 'tense' [0 hens]

Medial : 'native' [neitiv]

Final

$$
\text { : 'put' }\left[p^{\text {hh } u t]}\right.
$$

\section{ENGLISH}

Voiced

Alveolar :

Stop

Aspirated

\section{PHONEMIC OPPOSITIONS}

\section{BAHASA INDONESIA}

'tidur' [tidur] $=$ sleep

'atap' $[$ atap $]=$ roof

'kuat' $[$ kuat $]=$ strong

\section{PHONETIC FEATURES}

\subsubsection{Phoneme / d / in English}

The / d / phoneme in English occurs in word initial, medial and final positions, but the Indonesian / $\mathrm{d} /$ comes out only in initial and medial positions. In other words, the Indonesian / d / emerges initially in the syllable. The letter ' $d$ ' at the end of the Indonesian word is represented by the phoneme / $\mathrm{t} /$ because / $\mathrm{d} /$ does not emerge in this position. It is necessary to state here that the Indonesian / $\mathrm{d} /$ be made by putting the tip of the tongue slightly further back than for the phoneme $/ \mathrm{t} /$, and as a result, it is a little bit difficult for the twenty students of this study to pronounce the English / $\mathrm{d} /$ appearing in the final position. They tend to pronounce the voiced sound [d] either into a devoiced [] or into an unaspirated dental [ $\underline{\mathrm{t}}$ ]. To know the differences of the / $d$ / phoneme between English and Indonesian, the following are their phonemic oppositions and phonetic features.

\section{PHONEMIC OPPOSITIONS}

\section{ENGLISH}

Initial : 'date' [deit]

Medial : 'indicate' [indikeit]

Final : 'blind' [blaind]

\section{BAHASA INDONESIA}

'daftar' [daftar] = list

'hadiah' [hadiah] = prize

'abad' [ abat ]

\section{ENGLISH}

Voiced

Alveolar

Stop

\section{PHONETIC FEATURES \\ BAHASA INDONESIA}

$\begin{array}{ll}+ & + \\ + & + \\ + & +\end{array}$




\subsubsection{Phoneme / k / in English}

This phoneme also makes the 20 students of this study have problems when speaking English or reading an English text. They do so because the English / $\mathrm{k} /$ is aspirated but the Indonesian / $\mathrm{k}$ / is not. The English / $\mathrm{k} /$ phoneme emerges in three positions in the word - initial, medial and final, whilst, the Indonesian / k / phoneme just occurs in syllable - initial position. In other words, the phoneme / $\mathrm{k}$ / in Bahasa Indonesia comes out only in initial and medial positions, even though there are some words which end in the letter ' $\mathrm{k}$ '. If final ' $\mathrm{k}$ ' does happens, there are two differences in articulating it. For examples, firstly, some speakers of Bahasa Indonesia pronounce it as a regular / $\mathrm{k}$ / without being released as in English, but majority of them replace it with a glottal stop [?]. Consequently, it is difficult for the twenty students of this study to pronounce English words having the English / $\mathrm{k}$ / with aspiration especially when it appears in the initial and final positions where they pronounce / $\mathrm{k} /$ with the voiceless glottal stop [?].

To recognize the discrepancies, the following are their analyses presented below.

$\begin{array}{ll} & \text { ENGLISH } \\ \text { Initial } & \text { : 'kid' [kid] } \\ \text { Medial } & \text { : market' [ma:kit] } \\ \text { Final } & \text { : 'pick' [pik] }\end{array}$

\section{ENGLISH}

Voiced

Velar

Stop

Aspirated

\section{PHONEMIC OPPOSITIONS}

BAHASA INDONESIA

'kita' $[$ kita $]=$ we

'bakat' [bakat] $=$ talent

'botak' [botak] = bald

\section{PHONETIC FEATURES}

\subsubsection{Phoneme / g / in English}

The English phoneme / g / also makes the twenty students of this study obtain troubles in pronouncing English words having this phoneme, even though this / g / phoneme is not aspirated, and neither is the Indonesian / $\mathrm{g} /$. The phoneme / g / in English exists in word initial, medial, and final positions, but the phoneme / $\mathrm{g} /$ in Bahasa Indonesia appears only in initial and medial positions. The Indonesian language has very few words ending in the letter 'g', not including '-ng', and when it really comes out in the final position, it would be pronounced by many Indonesian speakers as [ $\mathrm{k}$ ] or as a glottal stop [? ]. As a result, many Indonesian students are unable to pronounce English words properly having the final $/ \mathrm{g} /$. The students include it with voiceless velar stop [ $\mathrm{k}]$, or with a devoiced [ $\breve{\mathrm{g}}]$.

In line with the findings of students' pronounces of the phoneme / g / in Bahasa Indonesia and English, the following are their analyses:

$\begin{array}{lll} & & \text { PHONEMIC OPPOSITIONS } \\ \text { Initial } & \text { ENGLISH } & \text { BAHASA INDONESIA } \\ & \text { ' gain' [gein] } & \text { 'gatal' }[\text { gatal] }=\text { itching }\end{array}$


$\begin{array}{ll}\text { Medial } & \text { : 'eager' [i:gə] } \\ \text { Final } & \text { : 'tag' [tæg] }\end{array}$

\section{ENGLISH}

$\begin{array}{ll}\text { Voiced } & : \\ \text { Velar } & : \\ \text { Stop } & : \\ \text { Aspirated } & \text { : }\end{array}$

\section{PHONETIC FEATURES}

'lagi' [lagi] = again

'budeg' [budək] $=$ deaf

\subsubsection{Phoneme / t / in English, and phoneme / c / in Bahasa Indonesia}

The English phoneme / $\mathrm{t} / \mathrm{also}$ puts the twenty students of this study get problems when they speak English and read an English text. They cannot pronounce English words having this phoneme fluently and perfectly. They do so because of the positions and features of this English phoneme are different from the Indonesian phoneme / $\hat{c} /$. The English / $t \mathrm{~g} /$ emerges in word initial, medial, and final positions, but the Indonesian / $\hat{c}=\mathrm{t} /$ occurs only in initial and medial positions.

The phoneme $/ \mathrm{t} /$ in English is a voiceless palato-alveolar while the phoneme $/ \hat{c}=t /$ in Bahasa Indonesia is a voiceless palatal stop. The phoneme / $\mathrm{t} /$ in English is pronounced with rounded lips, but the phoneme / $\hat{c}$ / in Bahasa Indonesia uttered with the tongue that is usually very far back in the mouth, and is also pronounced with spread lips by Indonesian speakers included the twenty students of this study. As a result, the students have problems to articulate the final sound of / $\mathrm{t} /$ phoneme in English because this sound in Bahasa Indonesia does not appear in this position. To know their phonemic oppositions and phonetic features, the following are their analyses.

\section{PHONEMIC OPPOSITIONS}

\section{ENGLISH}

Initial

$$
\text { : ‘charm' [tfa:m] }
$$

Medial

: ' trenchant' [trent $\left.\int ə n t\right]$

Final

$$
\text { : ‘teach' [ti: t5] }
$$

\section{BAHASA INDONESIA}

'cinta' $[$ ĉinta $]=$ love

'laci' [laĉi $]=$ drawer

Nothing

PHONETIC FEATURES 
Voiced

Palato-alveolar

Affricative

Rounded

\section{ENGLISH}

BAHASA INDONESIA

\subsubsection{Phoneme $/ \mathrm{d} / \mathrm{s}$ in English $=$ Phoneme $/ \hat{\mathrm{j}} /$ in Bahasa Indonesia}

As stated previously that all English phonemes analyzed before, make the twenty students of this study undergo problems in pronouncing English words. This phoneme / d 3 / in English also puts the students get troubles articulate English words. The phonemic opposition of the English phoneme / dz / comes out in three positions in English words. It can be in the word initial, medial, and final positions, but the Indonesian phoneme / $\hat{\jmath} /$ just appears in word initial and medial positions. The / d / / in English is rounded but the / $\hat{j} /$ in Bahasa Indonesia is not.

In English, this phoneme / dz / is voiced palate-alveolar, while / $\hat{j} /$ in Indonesian is voiced palatal stop. This phoneme / d $/$ / in English is sometime represented by the letter ' $\mathrm{g}$ ' that appears in the middle of the word, but the phoneme $/ \hat{\mathrm{j}} /$ in Bahasa Indonesia is not. These discrepancies cause the twenty students of this study get trouble in pronouncing English words possessing this phoneme. To know the differences, the following are the analyses presented as follows.

\section{PHONEMIC OPPOSITIONS}

\section{ENGLISH}

Initial

$$
\text { : ‘jam' [dzæm] }
$$

Medial

$$
\text { : ‘margarine' [ma:dzəri:n] }
$$

Final

$$
\text { : 'marge' [ma:dz] }
$$

\section{BAHASA INDONESIA}

‘jalan’ [jalan] = street

'telanjang' [təlanĵạ] = naked

Nothing

\section{PHONETIC FEATURES}

\section{ENGLISH}

Voiced

Palato-alveolar

Affricative

Rounded

:
:
:

\section{BAHASA INDONESIA}

+
+
+
+

\subsubsection{Phoneme / f / in English}

The phoneme / f / in English and in Bahasa Indonesia appears on three places, initial, medial, 
and final positions. Actually, the Indonesian phoneme / f / is derived from loan words only for instance from foreign languages: Arabic and Western European languages. Several words of Bahasa Indonesia having an ' $\mathrm{f}$ ' can be replaced by ' $p$ ' letter, but not every ' $\mathrm{p}$ ' may interchange with ' $\mathrm{f}$ ', for instance:

We can say: [sifat] or [sipat] = temper, [syaraf] or [sarap] = nerve, [fakir] or $[$ pakir] $=$ poor, but we cannot say: [fintar] for $[$ pintar] $=\operatorname{clever,~[fajak]~for~}[$ pajak] $=\operatorname{tax},[$ faku] for $[$ paku $]=$ nail, [fantas] for $[$ pantas $]=$ appropriate, $[$ fisau $]$ for $[$ pisau $]=$ knife .

Frankly speaking, by this phoneme / f /, the Indonesian students in general do not have problems to pronounce the English words having this sort phoneme / $\mathrm{f} /$ because most of them are so familiar with it. In essence, this / $\mathrm{f} /$ phoneme in Bahasa Indonesia resembles the sound in English. The following are its analyses as follows.

\section{PHONEMIC OPPOSITIONS}

\section{ENGLISH}

Initial : 'face' [feis]

Medial : 'define' [difain]

Final : 'deaf' [def]

\section{BAHASA INDONESIA}

'fitnah' [fitnah] = slander

'lafal' [lafal] = pronunciation

'taraf' [taraf $]=$ standard

\section{PHONETIC FEATURES}

\section{ENGLISH}

BAHASA INDONESIA

Voiced

Labio-dental

Affricative

\subsubsection{Phoneme / v / in English}

This phoneme / v / also disturbs the twenty students of this study to pronounce the English words having it. The students do so because this phoneme / $\mathrm{v} /$ does not exist in Bahasa Indonesia phonological system. Almost all Indonesian words having this letter ' $\mathrm{v}$ ' are derived from European languages. Consequently, wherever this letter ' $v$ ' occurs in an Indonesian word, it is generally pronounced as / $\mathrm{f} /$ phoneme or / $\mathrm{p} /$ phoneme.

This phoneme / v / in English occupies three places in words. It can appear in word initial, medial and final positions, but it does not in Bahasa Indonesia. In essence, the twenty students of this study much have difficulty pronouncing English words possessing this sound

' $\mathrm{v}$ ' in all positions since this / $\mathrm{v} /$ is not used in the Indonesian phonological system. To know the phonemic oppositions and phonetic features, the following are its analyses.

\section{ENGLISH}

Initial : 'valid [vælid]

Medial : 'reveal' [rivi:1]

Final : 'solve' [solv]

\section{PHONEMIC OPPOSITIONS}

\section{BAHASA INDONESIA}

'validitas' [faliditas] or [paliditas] = state of being valid

'reviu' [rifiu] or [ripiu] = review

Nothing 


\section{PHONETIC FEATURES}

\section{ENGLISH}

\section{BAHASA INDONESIA}

Voiced

Labio-dental

Fricative

\subsubsection{Phonemes / $\theta$ / and / $\partial$ / in English}

These two phonemes / $\theta$ / and / $ð$ / absolutely bother the twenty students of this study to speak English and read an English text. They occupy three places in English words, for instance, they can appear in word initial, medial and final positions, but they do not in Bahasa Indonesia because they are not known and exerted in the phonological sound and writing systems of Bahasa Indonesia. As a result, it is very difficult for the twenty students of this study to pronounce English words having either $/ \theta /$ or $/ \partial /$. The students are inclined to pronounce them as $/ \mathrm{t} /, / \mathrm{d} /$ and $/ \mathrm{s} /$. Generally acknowledged that wherever Indonesian words in which the letters 'th' involved, are loan words from foreign languages. The aforementioned students tend to pronounce the English words:

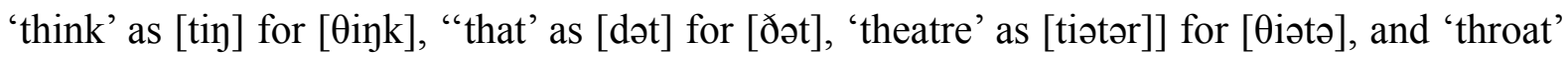
as [troat] or [sroat] for [ $\theta$ rout].

To recognize the phonemic oppositions and phonetic features of these phonemes / $\theta$ / and / $/$, the following are their analyses presented below.

\begin{tabular}{|c|c|c|c|}
\hline \multicolumn{4}{|c|}{ PHONEMIC OPPOSITIONS } \\
\hline & ENGLISH & BAHASA & INDONESIA \\
\hline Initial & : 'third' $[\theta ə: \mathrm{d}]$ & & \\
\hline $\begin{array}{l}\text { Medial } \\
\text { Final }\end{array}$ & 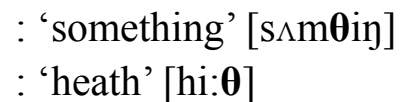 & Nothing & \\
\hline
\end{tabular}

\section{ENGLISH}

PHONETIC FEATURES

Voiced

Dental

$$
\text { : }
$$

Fricative

\subsubsection{Phoneme / s / in English}

The phoneme / s / in English appears on three places, and so does the phoneme / s / in Bahasa Indonesia, but the Indonesian phoneme / s / is distinct from the English phoneme / s / where the English / s / is sometime articulated as [ z ] or [ s ]. Whilst, the Indonesian phoneme / s / is never pronounced $[\mathrm{z}$ ] wherever it occurs in the word. In English, for instance, the letter ' $\mathrm{s}$ ' is articulated as $[\mathrm{z}]$ when it comes out after the letter having the voiced sound, especially in the final position (Gimson, 1980) such as: 'peas' [pi:z], 'knickers' [nikəz], 'mews' [mju:z], 'news' [nju:z], 'nowadays' [nauədeiz].

In line with the above discrepancies, it can be said that any English words having the phoneme / s / are pronounced as / s / rather than / z / by the twenty students of this study. To 
know its phonemic oppositions and phonetic features, the following are its analyses presented below.

\section{PHONEMIC OPPOSITIONS}

\section{ENGLISH}

Initial : 'sack' [sæk]

Medial : 'positive' [pozitiv]

Final : 'precise' [prisais]
BAHASA INDONESIA

'sakit' [sakit] = sick

'kasar' [kasar] = rude

'lemas' [ləmas $]=$ limp

\section{PHONETIC FEATURES}

\section{ENGLISH}

Voiced

Alveolar

Fricative

:

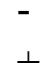

$+$

\section{BAHASA INDONESIA}

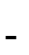

$+$

$+$

\subsubsection{Phoneme / z / in English}

In line with the findings of this study, it is discovered that this phoneme / $\mathrm{z} /$ seems not to disturb the twenty students of this study in pronouncing the English words possessing it initially and medially, except when it occurs in the final position because the Indonesian / z / does not appear in this position.

Pertaining to the above difference, it is unearthed that if the ' $z$ ' in English appears in the final position, the aforementioned students are likely to pronounce it as ' $\mathrm{s}$ ' rather than ' $\mathrm{z}$ '.

The other differences deal with the phonemic oppositions and phonetic features of the phonem / z / in English and Bahasa Indonesia. The following are its analyses stated below.

\section{PHONEMIC OPPOSITIONS}

\section{ENGLISH}

Initial : 'zip' [zip]

Medial : 'zigzag' [zigzæg]

Final : 'zounds' [zaundz]
BAHASA INDONESIA

'zakat' [zakat] $=$ tithe

'lezat' [lêzat] = delicious

Nothing

\section{PHONETIC FEATURES}

\section{ENGLISH}

Voiced

Alveolar

$$
\text { : }
$$

$+$

BAHASA INDONESIA

Fricative

\subsubsection{Phoneme / $\mathrm{s} /$ in English $=/ \hat{\mathrm{s}} /$ in Bahasa Indonesia}

The English phoneme / s / emerges in three areas in the word initial, medial and final positions, but the Indonesian phoneme / $\hat{\mathrm{s}} /$ appears only in word initial and medial positions. Bahasa Indonesia has this sound of / $\hat{\mathrm{s}} /$ in the sound system but it is represented with letters 'sy' in the writing system. When the letters 'sy' materialize in Indonesian words, they have the sound 
symbol / $\hat{\mathrm{s}} /$. However, the twenty students of this study are found to pronounce the phoneme / $\hat{\mathrm{s}}$ / instead of the phoneme / $\mathrm{s} /$ as in:

'syahdu' [ŝahdu] = calm, serene, 'syahwat' [ŝahwat] = lust/orgasm 'tamasya' [tamaŝa] = pignic, 'masyarakat' [maŝarakat] = society

The sound of / s / in English is slightly different from the sound of / $\hat{\mathrm{s}}$ / in Bahasa Indonesia where the English / s / is rounded while the Indonesian / $\hat{\mathbf{s}} /$ is not. As a result, the 20 students still have problems in articulating the English phoneme / $\mathrm{s} /$ in the word initial and medial, and the final positions, because the English phoneme / $/$ / is sometimes represented by letters 'ch, sh, -tion' in the word medial position. The following are their phonemic oppositions and phonetic features displayed respectively.

\section{PHONEMIC OPPOSITIONS}

\begin{tabular}{|c|c|c|}
\hline & ENGLISH & BAHASA INDONESIA \\
\hline nitia & : 'ship’ [sip] & 'syukur' $[$ ŝkur $]=$ thank God \\
\hline & : ‘nation’ [neisən]; 'machine' [məsin] & 'isyarat' [iŝarat $]=$ signal \\
\hline & : 'mash' [mæs] & Nothing \\
\hline
\end{tabular}

\section{PHONETIC FEATURES}

\section{ENGLISH}

Voiced

Palato-alveolar

Fricative

\subsubsection{Phoneme / 3 / in English}

Gimson (1980) states that the phoneme / 3 / in English rarely appears in the word initial and final positions. The phoneme / 3 / occurs only in loan words, for instance in the word initial: 'gigolo' [3igəlou], 'gigue'[3ig], 'genre' [3enrə], 'jalousie' [3æluzi], and in the word final as in: 'prestige' [presti3], 'barrage' [bæra3], 'rouge' [ru3].

The English phoneme / 3 / really makes the twenty students of this study to pronounce the English words possessing this phoneme. It is discovered that the palato-alveolar $/ 3 /$ in English is relatively complex for the aforementioned students of this study because Bahasa Indonesia does not have the phoneme / $3 /$ in the sound and writing systems. The survival of placeantagonisms between alveolar / s and $\mathrm{z} /$, and palate-alveolar / $3 /$ areas of articulation demands a accuracy of pronunciation in English which is not wanted by languages lacking, for example, Bahasa Indonesia (The Indonesian Language). Consequently, the nonexistence of palate-alveolar fricative phoneme / $3 /$ in Bahasa Indonesia permits the reaction of utterances in the alveolar region /s and $\mathrm{z} /$. The students tend to substitute the sound $/ 3 /$ with either / z / or / s /, for instances: 'treasure' [trzzə] for [trezə], 'pleasure' [plesə] for [plezə].

To know its phonemic oppositions and phonetic features, the following are its analyses presented below. 
ENGLISH

Initial : Infrequent

Medial : 'leisure' [le3ə]

Final : Infrequent

\section{ENGLISH}

\section{PHONETIC FEATURES}

Voiced

Palato-alveolar :

Fricative

\section{PHONEMIC OPPOSITIONS}

\section{BAHASA INDONESIA}

Nothing

\subsubsection{Phoneme / h / in English}

The English phoneme / h / comes out only in word initial and medial positions, but the Indonesian phoneme / h / appears in the three positions, initial, medial and final positions, and it is plainly uttered in the final position. When it exists in word medial position in Bahasa Indonesia, it is articulated in two possible ways, firstly, the / $\mathrm{h} /$ is clearly pronounced when it is pinched by two similar vowels as in: 'bahan' [bahan] = material, 'lahap' [lahap] = ravenous, and secondly, the Indonesian phoneme / h / is either gently articulated or entirely dropped when it is pinched by two dissimilar vowels, for instance, 'pahit' [pand $\mathrm{pr}^{\mathrm{h}}$ [pait] = bitter,

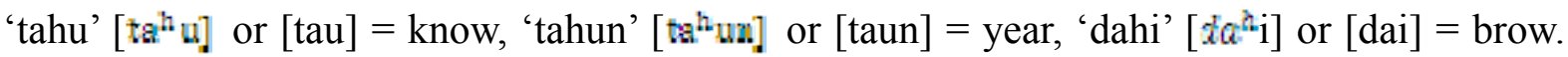
On the other hands, the English phoneme / h / is sometimes fortis, and sometimes silent completely as in:

'hail' [heil], 'habit' [hæbit], 'ham' [hæm]; 'honour' [ənə], 'honesty' [ənisti], 'hostler' [əslə].

To know the discrepancies of phonemic oppositions and phonetic features between English and Bahasa Indonesia sound systems, the following are the analyses as follows.

\section{ENGLISH}

Initial : 'hand' [hænd]

Medial : 'cohesion' [kouhi:3ən]

Final : Nothing

\section{PHONEMIC OPPOSITIONS}

\section{BAHASA INDONESIA}

'harus' [harus] = must

''lahir' [lahir] = born

'letih' $[$ lətih $]=$ tired

\section{ENGLISH}

\section{PHONETIC FEATURES}

Voiced

Glottal

Fricative :

\subsubsection{Phoneme / 1 / in English}

The English phoneme / 1/ appears in word initial, medial, and final positions, so does the 
Indonesian phoneme / 1 / However, the Indonesian / $1 /$ is pronounced clearly wherever it emerges in the word, but within the / 1 / phoneme in English, three allophones come out as in:

1. : Clear [1], with a relatively front vowel quality, before vowels as in 'lick' [lik], 'bill' [bil], ' mill' [mil], '

2. : Voiceless [ 1 ], sticking to accented / p, k / as in 'place' [pleieis], 'class' [kḷa:s]

3. : Dark [ 1 ], with a rather back vowel quality, finally after a vowel, before a consonant, and as a syllabic sound falling as a consonant, as in 'heel' [hi:ł], 'triple' [tripł].

With respect to the above descriptions, it can be said that although the / $1 /$ in Bahasa Indonesia is different from the / 1 / in English, the aforementioned students do not so much have difficulty to pronounce English words having the clear / 1/, except the dark / $1 /$ and the silent [ 1 ] as in 'walk' [wok], is pronounced by them as [wolk], folk'[fok] is pronounced [folk]. The following are its phonemic opposition and phonetic features as follows.

\section{PHONEMIC OPPOSITIONS}

\section{ENGLISH}

Initial : 'loose' [lu:s]

Medial : 'pilot' [pailət]

Final : 'pill' [pil]
BAHASA INDONESIA

'luka' [luka] = wounded

'keliling' [kəlilin] = around

'tebal' $[$ təbal $]=$ thick

\section{PHONETIC FEATURES}

\section{ENGLISH}

Voiced

Alveolar

$$
\text { : }
$$

Lateral
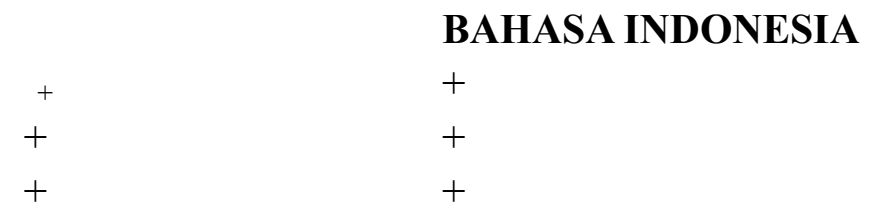

1.4.18 Phoneme / $\mathrm{r} /$ in English

The English phoneme / $\mathrm{r} /$ is a voiced post-alveolar approximant appearing only in word initial and medial positions, except when the word final $\{/ \mathrm{r} /$-link with following word beginning with a vowel\} Gimson (1980), as in 'for example' [fərekza:mpl]. However, the / r / in American English is a little clear in the final position in the word. Whereas, the Indonesian phoneme / $\mathrm{r} /$ is an apical post-dental trill, and it can fill three positions in the Indonesian words. Accordingly, the 20 aforementioned students of this study tend to pronounce / r / clearly wherever it occurs in the word since in Bahasa Indonesia this phoneme / $\mathrm{r} /$ absolutely articulate clearly. To know the differences of this / $\mathrm{r} /$ phoneme, the following are its phonemic oppositions and phonetic features as follows.

\section{PHONEMIC OPPOSITIONS}

\section{ENGLISH}

Initial : 'rate' [reit]

Medial : 'arrive' [oraiv]

\section{BAHASA INDONESIA}

'rumah' [rumah] = house

'dorong' [doron] = push 
Final : 'keeper' [ki:pə ( r )]

'telur' [təlur] = egg

\section{ENGLISH}

\section{PHONETIC FEATURES}

Voiced

Post alveolar

Approximant

\subsubsection{Phoneme / w / in English}

The / w / phoneme in English and Bahasa Indonesia comes out only two places in the word initial and medial. The English phoneme / w / is pronounced with a substantial bulge/ prominent tips as in 'wont' [wount], 'reword' [ri:wə:d]. The Indonesia / w /, however, is created with much less lip prominent. It is symbolized by the letter ' $u$ ' when it appears after a vowel as in 'keuangan' [kəwayan].

Furthermore, the Indonesian / w / does not have any variations, but the English / w / does, for example, the phoneme / $\mathrm{w} /$ in English is devoiced particularly after diacritical mark / $\mathrm{t}, \mathrm{k} / \mathrm{as}$ in 'twist' [twist], 'twit' [tŵit], 'quick' [kŵik], quid' [kwiid]. The twenty students of this study are discovered having problems when the English word begins the letter ' $w$ ' initially followed by the letter ' $r$ '. Almost all students pronounce such words incorrectly, as in 'wrap' [wrap] for [ræp], 'wreck' [wrek] for [rek], 'wrinkle' [wrijkl] for [rijkl]. The students do it so because they do not know that when the English cluster consonants / wr- / appear initially in the word, the letter ' $w$ ' is silent.

To know the dissimilarities of this / w/ between English and Bahasa Indonesia, the following are the phonemic oppositions and phonetic features presented below.

\section{PHONEMIC OPPOSITIONS}

$\begin{array}{lll} & \text { ENGLISH } & \text { BAHASA INDONESIA } \\ \text { Initial } & \text { : 'wait' [weit] } & \text { 'waktu' }[\text { waktu] }=\text { time } \\ \text { Medial } & \text { : 'towel' [tavəl] } & \text { 'rawa' [rawa }=\text { bush } \\ \text { Final } & \text { : Nothing } & \text { Nothing }\end{array}$

\section{PHONETIC FEATURES}

\section{ENGLISH}

Voiced

Labio-velar

+
+
+

\section{BAHASA INDONESIA}

Approximant

1.4.20 Phoneme / j / in English $=/ \mathrm{y} /$ in Bahasa Indonesia

The English phoneme / $\mathrm{j} /$ and the Indonesian phoneme / y / come out only in word initial and medial positions. The English phoneme / $\mathrm{j} /$ possesses the palatal (front unrounded) partially vowel ' $j$ ' (relating to ' $i$ ', while the phoneme / y / in Bahasa Indonesia has a partial vowel sound included all glides from the position of the vowel ' $i$ ' to the position of a following vowel, and/or from the position of a preceding vowel to the position of the vowel ' $\mathrm{i}$ '. As a 
result, the 20 aforementioned students face problems in pronouncing the English words having this phoneme since the English / $\mathrm{j}$ / is palatalized. To know the phonemic oppositions and phonetic features of both phonemes, the following are their analyses.

\section{PHONEMIC OPPOSITIONS}

\section{ENGLISH}

Initial : 'yaw' [jo:]

Medial : 'lawyer' [lo:jə ( r )]

Final : Nothing
BAHASA INDONESIA

'yakni' [yakni] = namely

'layak' [layak] = appropriate

Nothing

\section{PHONETIC FEATURES}

\section{ENGLISH}

BAHASA INDONESIA

Voiced

Unrounded-palatal

Approximant

+
+
+

$+$

$-$

$+$

\subsubsection{Phoneme / m / in English}

The phoneme / m / in English and Bahasa Indonesia occupy in word initial, medial and final positions, and the Indonesian phoneme $/ \mathrm{m} /$ is similar to the sound of the phoneme $/ \mathrm{m} / \mathrm{in}$ English. As a result, the 20 previous students of this study do not have problems in pronouncing English words possessing this phoneme. Let's consider its phonemic oppositions and phonetic features below.

\section{PHONEMIC OPPOSITIONS}

\section{ENGLISH}

Initial : 'mad' [mæd]

Medial : :scamper' [skæmpə ( r ) ]

Final : 'pilgrim' [pilgrim]

\section{BAHASA INDONESIA}

'makan' $[$ makan $]=$ eat

'bermalam [bormalam] $=$ spend the night

'tikam' [tikam] $=$ stub

\section{PHONETIC FEATURES}

\section{ENGLISH}

\section{BAHASA INDONESIA}

Voiced

$+$

Bilabial :

Nasal

$+$

\subsection{The phoneme / $\mathrm{n} /$ in English}

The English phoneme / $\mathrm{n} /$ appears in word initial, medial, and final positions, and so does the Indonesian phoneme / $\mathrm{n} /$. The English / $\mathrm{n} /$ suits the dental / $\mathrm{n} /$ when it emerges before a dental fricative as in 'tenth' [ $\operatorname{t\varepsilon n} \theta$ ], and the Indonesian / $\mathrm{n} /$ does, too, as in 'tentara'

[təntara] $=$ army. Consequently, the phoneme / $\mathrm{n} /$ does not make trouble to the 20 students of this study in articulating the English words having this phoneme. The following are its phonemic oppositions and phonetic features presented below. 


\begin{tabular}{|c|c|c|}
\hline & \multicolumn{2}{|c|}{ PHONEMIC OPPOSITIONS } \\
\hline & ENGLISH & BAHASA INDONESIA \\
\hline Initial & : ‘nail' [neIl] & 'nakal' [nakal] = naughty \\
\hline Medial & : 'manage' [mænId3] & 'manis' $[$ manis $]=$ sweet, beautiful \\
\hline Final & : ‘lean’ [li:n] & 'taman' $[\operatorname{taman}]=$ park \\
\hline
\end{tabular}

\section{ENGLISH}

Voiced

Alveolar

Nasal

\section{PHONETIC FEATURES}

\subsection{Phoneme / $\mathrm{y} /$ in English}

The English / y / comes out only in word medial and final positions but the Indonesian / y / can appear in word initial, medial and final positions. The phoneme / $\mathrm{y} /$ in Bahasa Indonesia is represented in the writing system as ' $\mathrm{ng}$ '. In essence, since the phoneme / $\mathrm{y} /$ is similar to the sound of $/ \mathrm{g} /$ in English, the 20 students of this study have no problems in pronouncing English words possessing the phoneme / $\mathrm{y} /$. Let's consider the following its phonemic oppositions and phonetic features below.

\section{PHONEMIC OPPOSITIONS}

\section{ENGLISH}

Initial : Nothing

Medial : 'angry' [ængri]

Final : 'long' [lon]

\section{BAHASA INDONESIA}

'ngantuk' [nantuk] = sleepy

'tangan' $[\tan a n]=$ hand

'lambang' [lamban] = symbol

\section{PHONETIC FEATURES}

\section{ENGLISH}

Voiced

Velar

Nasal

\section{Vowels}

\subsection{Phoneme / $i$ / in English}

The vowel sound of / i / in English and Bahasa Indonesia is differentiated primarily by two aspects namely the position of the tongue in the mouth and the shape of the lips. The

/ i / vowel in both languages appears in word initial, medial and final positions. The English phoneme / i / is high, front and unrounded and so does the Indonesian phoneme / i /, and it has one variant that is / I /, but no allophonic variants. The Indonesian phoneme / $\mathrm{i} /$ possesses two allophones, one is short vowel appearing in a closed syllable as in the English vowel sound 'since' [s Ins] equals to 'sintir' [s $\operatorname{sint} I r]=$ dice, and the other one is long vowel occurs 


\section{Macrothink}

in an open syllable as in the English sound vowel 'before' [b Ifo:] equals to 'bisik' [b Is Ik] = whisper.

Based on the above differences, the 20 students of this study still face problems pronouncing English words holding this variant. They students are inclined not to differentiate the pronunciations between 'bead' [bi:d] and 'bid' [bid]. They do not know that the English phoneme / i / and / I / are separate phonemes because bearing different meanings in the word. To recognize the discrepancies, the following are its phonemic opposition and phonetic features.

$\begin{array}{llc} & \text { ENGLISH } & \text { PHONEMIC OPPOSITIONS } \\ \text { Initial } & \text { : 'eager' [i:gə] } & \text { BAHASA INDONESIA } \\ \text { Medial } & \text { : 'delete' [d I li:t] } & \text { 'itu' [itu] }=\text { that } \\ \text { Final } & \text { : 'study' [st } \Lambda \text { d I }] & \text { 'derita' [dərita] }=\text { suffer } \\ & \text { 'mati' }[\text { mati] }=\text { die }\end{array}$

\section{ENGLISH}

\section{PHONETIC FEATURES}

$\begin{array}{llll}\text { High } & : & + & + \\ \text { Front } & : & + & + \\ \text { Rounded } & : & - & -\end{array}$

\subsection{Phoneme / u / in English}

The English phoneme / $\mathrm{u} /$ comes out only in word medial and final positions, but the Indonesian phoneme / $\mathrm{u} /$ appears in word initial, medial, and final positions. The English / $\mathrm{u} /$ possesses one variant such as / $v /$ without having allophonic alternatives. They are independent phonemes in English but not in Bahasa Indonesia because they do not transmit any meanings in the Indonesian phonological system. The Indonesian phoneme / $\mathrm{u} /$ appears in an open syllable as in 'tutup' [tutup] = shut, and the / $v /$ occurs in a closed syllable as in 'tumbuh' [tombuh] $=$ grow. In short, the $/ v /$ in Bahasa Indonesia can occur either before or after another vowel, for examples: / au, ua, ui, iu, ue / as in 'aula' [avla] = hall, 'uap' [vap] = steam, 'uik' [vik] = squeal, 'ciut' [civt $]=$ shrunken' 'kuek' $[$ kvek $]=$ noise.

In addition, the 20 students of this study are discovered not able to differentiate the short sound of $/ v /$ and the long one / $u$ / in English. As a result, when those students pronounce English words having the phoneme / $\mathrm{u} /$, they are affected by the Indonesian / $\mathrm{u} /$, for example, they may articulate 'cook' [kuk] should be [kok]. The following are its phonemic oppositions and phonetic features presented below.

\section{ENGLISH}

$\begin{array}{ll}\text { Initial } & \text { : Infrequent } \\ \text { Medial } & \text { : 'book' [buk] } \\ \text { Final } & \text { : 'do' }[\mathrm{du}]\end{array}$

\section{PHONEMIC OPPOSITIONS}

\section{BAHASA INDONESIA}

'utang' $[\mathbf{u t a n}]=$ debt

'belum' [bəlum] = not yet

'tamu' $[\operatorname{tamu}]=$ guest 


\section{PHONETIC FEATURES}

ENGLISH

High

Back

Rounded :
BAHASA INDONESIA

$+$

$+$

$+$

\subsection{Phoneme $/ e=\varepsilon /$ in English}

The English phoneme / $\mathrm{e}=\varepsilon$ / comes out only in the word initial and medial positions but the Indonesian phoneme / $\mathrm{e}=\varepsilon$ / occupies three places such as in the word initial, medial and final positions. Almost all 20 students of this study are found able to pronounce the English phoneme / $\mathrm{e}=\boldsymbol{\varepsilon} /$ fluently. They can do it so because the / $\boldsymbol{\varepsilon} /$ in Bahasa Indonesia has two allophones, firstly, when it appears in a closed syllable, it is a sound like the English sound in 'beg' [bsg] or [beg]. Secondly, when it occurs in an open syllable it is like the English diphthong in 'lay' [lei], 'bay' [bei], 'pay' [pei]. As a result, the previous students do not face much difficult to pronounce English words having this phoneme. Below are its phonemic oppositions and phonetic features.

\section{PHONEMIC OPPOSITIONS}

\section{ENGLISH}

Initial : 'elder' [eldə]

Medial : 'peg' [peg]

Final : Nothing

\section{ENGLISH}

Medial :

Front

Rounded

\section{BAHASA INDONESIA}

'enak' $[$ enak $]=$ delicious

'kelereng' [kəleren] = marble

'gue' [gue] = I or me

\section{PHONETIC FEATURES}

\section{BAHASA INDONESIA}

$+$

$+$

\subsection{Phoneme / a / in English}

The English phoneme / æ / comes out only in the initial and medial positions in the word but the phoneme $/ æ /$ emerges neither in the phonological system nor in the writing system of Bahasa Indonesia. This phoneme $/ \mathfrak{x} /$ is almost the same as [e] where the mouth is slender more open than for / e / where the quality of the phoneme / æ / is close to cardinal vowel / $\varepsilon$ / than to cardinal [a] that equals to $[\varepsilon]$. Accordingly, almost all 20 students of this study are likely to substitute the phoneme / æ / with $[\varepsilon]$ or / e / wherever it exists in English words since the English phoneme $/ æ /$ is unknown in Bahasa Indonesia. Subsequently are its phonemic oppositions and phonetic features presented below.

\section{PHONEMIC OPPOSITIONS}

ENGLISH

$\begin{array}{ll}\text { Initial } & \text { : 'abstract' [æabstrækt] } \\ \text { Medial } & \text { : 'back' [bak] } \\ \text { Final } & \text { : Nothing }\end{array}$

BAHASA INDONESIA

Nothing 
ENGLISH

Low

Front

Rounded

\section{PHONETIC FEATURES}

BAHASA INDONESIA

Nothing

\subsection{Phoneme / a / in English}

The English phoneme / a / emerges in the word initial, medial and final positions, but the / a / in Bahasa Indonesia does not appear in the word final position. The / ə / in English may be spelt with most vowel letters together their combinations, for examples: i, e, a, o, u, ar, er, or, ure, etc. (Gimson, 1987). Besides, in the writing system of Bahasa Indonesia, the phoneme / a / is symbolized by the letter 's'. Consequently, it has been discovered that the 20 students of this study also face problems in uttering the English words having this phoneme. The following are its phonemic oppositions and phonetic features displayed below.

\section{PHONEMIC OPPOSITIONS}

\section{ENGLISH}

Initial : 'above' [əob $\mathrm{v}]$

Medial : 'learn' [lə:n]

Final : 'reader' [ri:də]
BAHASA INDONESIA

'engkau' [əךkau] = you

'benar' [bənar] = right, correct

Nothing

\section{PHONETIC FEATURES}

\section{ENGLISH}

\section{BAHASA INDONESIA}

Central :

Mid

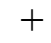

Rounded :

\subsection{The phoneme / 1 / in English}

The English phoneme / $\Lambda$ / occupies three places in the words, such as in word initial, medial, and final positions. The quality of this $/ \Lambda /$ often happens together that of unaccented

/ $\boldsymbol{\partial}$ / where they are being central vowel. In most cases, the English / $\Lambda$ / is derived from a vowel $+/ \mathrm{r} /$ as the spellings demand. It is always decreased to / $\boldsymbol{\partial} /$ when it is related to no sort of stress-accent as in 'wert' [w $: \mathrm{t}$ ], except [wə] (Gimson, 1987). In line with the English phoneme $/ \Lambda /$, this phoneme is unknown in the Indonesian phonological system. However, it is found that almost all 20 students of this study replace / $\Lambda$ / with / $/$ / sound because this / $\boldsymbol{\partial}$ / in Bahasa Indonesia has a similar characteristic as / $\Lambda$ / in English based on the phonetic feature that both $/ \Lambda /$ and / $\boldsymbol{\partial} /$ being central vowel. As a result, the aforementioned students of this study still undergo problems when pronouncing the English words possessing it. Below are its analyses via phonemic oppositions and phonetic features.

\section{ENGLISH}

Initial $\quad$ : 'earth' $[\Lambda: \theta]$

Medial : 'person' [p :sn]

\section{PHONEMIC OPPOSITIONS}

\section{BAHASA INDONESIA}

Nothing 
Final : 'purr' $[p \wedge:]$ 2013, Vol. 1, No. 3

\section{ENGLISH}

Central :

Mid :

Rounded :

\section{PHONETIC FEATURES}

\section{BAHASA INDONESIA}

Nothing

\subsection{Phoneme / a / in English}

The phoneme / a / in both English and Bahasa Indonesia emerges three locations in the words, for instance, in the word initial, medial and final positions. The Indonesian phoneme / a / in the writing system is represented by the letter ' $a$ ', and it is never articulated as / æ/, but the English phoneme / a / has two major group words that indicate a variance from the Received Pronunciation (R.P) systems (Gimson, 1987).

Firstly, those cases of / a: / in RP in a syllable closed by / f, t, r, s and m, n / + consonant. For examples: 'crafty' [kra:fti], 'partner' [pa:tnə], 'bark' [ba:k], 'pardon' [pa:dn], 'bask' [ba:sk], 'palm' [pa:m] and 'darn' [da:n]. Secondly, Gimson (1987) proceeds stating that those words, primarily with vowel + ' $r$ ', now with / a: / in R.P., for instance, (art, hard, car, cart, large, heart). In the second examples, either / a / or / æ / is exerted. There are, however, in R.P. many cases in which / æ / rather than / a: / appears in these phonetic context (e.g. / a: / in 'pass, glass, chance, dance, demand / except / æ / in: / passage, ass, aster, gas./ Consequently, the 20 students of this study are discovered being confused in pronouncing the English words possessing this phoneme / a /. They are inclined to use / $\varepsilon=$ ə / instead of / æ / as in ' $g a s$ ' [ges] for / gæs /, 'ass' [\&s] for [æs]. To see its phonemic oppositions and phonetic features, the following are its analyses.

\section{ENGLISH}

$\begin{array}{ll}\text { Initial } & \text { : 'arm' }[\mathbf{a}: \mathrm{m}] \\ \text { Medial } & \text { : 'cart' [ka:t] } \\ \text { Final } & \text { : 'bra' [bra:] }\end{array}$

Final : 'bra' [bra:]

\section{ENGLISH}

Low

Central

Rounded

\section{PHONEMIC OPPOSITIONS}

\section{BAHASA INDONESIA}

'arti' [ar:ti] = mean

'baru' $[\mathrm{ba}: \mathrm{ru}]=$ new

'bawa' [ba:wa] $=$ bring, take

\section{PHONETIC FEATURES}

\subsection{Phoneme / $\Lambda$ / in English}

The English phoneme / $\Lambda$ / comes out only in word initial and medial positions, but the / $\Lambda$ / phoneme is not recognized in the Indonesian phonological sound system. This / $\Lambda /$ phoneme in English is spelt with most vowel letters and their combinations, for examples: -u-/ sun /, -o- / son /, -ou- / young /, -oo- / blood /, -oe- / does /. Sometimes, / $\Lambda$ / can complete the 
functions of a short open vowel contradicted to both / æ / and / a /. Since the English / $\Lambda$ / is represented by these letters, the 20 students of this study are unearthed having much difficulty in pronouncing English words owning the / $\Lambda$ / sound. Accordingly, they are inclined to exert / a / instead of / $\Lambda /$ as in 'loving' [lafin] for [1 $\Lambda v i]$. Let's consider its analyses via phonemic oppositions and phonetic features presented as follows.

$\begin{array}{llrl} & & \text { PHONEMIC OPPOSITIONS } \\ & \text { ENGLISH } & \text { BAHASA } & \text { INDONESIA } \\ \text { Initial } & \text { : 'upper' }[\Lambda \text { pə] } & \\ \text { Medial } & : \text { 'tub' }[\mathrm{t} \Lambda \mathrm{b}] & \text { Nothing } \\ \text { Final } & \text { : Nothing } & \end{array}$

\section{ENGLISH}

Low

Central

Rounded

\section{PHONETIC FEATURES}

\section{BAHASA INDONESIA}

Nothing

\subsection{Phoneme / $p$ / in English}

The English phoneme / $\mathrm{p} /$ disappears in word final position, except in word initial and medial positions. In other words, it does not emerge in a final open syllable, and it is spelt with most vowel letters as in: -o- / dog /, -a- / was /, -ou- / cough /, -ow- / knowledge /, -au- / because /, etc. and many words holding / p / $+/ \mathrm{f}, \mathrm{s} /$ which have an option pronunciation with / p /, for examples / off, cloth, cross / etc. (Gimson, 1987).

Evidently, the / $\mathfrak{D} /$ in Bahasa Indonesia is symbolized by the letter ' $\mathrm{o}$ ', and this phoneme / $\mathrm{D}$ / is an allophone of / o /. It comes out only in a closed syllable whether in the word initial position or in the word medial position but not in final position. In essence, the consequence of this fundamental pronunciation for the 20 students of this study is that the phoneme / $\mathrm{p} /$ possessing different spelling from its pronunciation that makes those students in a great difficulty to articulate acceptable English words having the sound of $/ \mathrm{p} /$. As a result, to be able to pronounce this sound they more possibly tend to exert / o / rather that / $\mathrm{p} / \mathrm{as}$ in: 'sock' [sok] for [spk], 'pop' [pop] for [ppp]. The following are its phonemic oppositions and phonetic features as follows.

\section{ENGLISH}

$\begin{array}{ll}\text { Initial } & : \text { 'obverse' [pbve:s] } \\ \text { Medial } & : \text { 'top' [top] }\end{array}$

Final : Nothing

\section{ENGLISH}

Back

Low

\section{PHONEMIC OPPOSITIONS}

\section{BAHASA INDONESIA}

'obor' [pbor] = torch

'’toga' [toga $]=$ academic gown

\section{PHONETIC FEATURES}

: +

\section{BAHASA INDONESIA}

$+$

$+$ 
Rounded

\subsection{Phoneme / o / in English = Phoneme / o / in Bahasa Indonesia}

The English phoneme / o / occupies three locations such as in word initial, medial and final positions, and so does the Indonesian / o / What different of this / $\mathrm{o} / \mathrm{in}$ both languages is that the Indonesian / o / is an allophone of / o /. When the letter ' $\mathrm{o}$ ' in Bahasa Indonesia appears in an open syllable, it is articulated very much like English sound in 'four' [fo:]. In other words, the / o / in Bahasa Indonesia becomes a long vowel when it occurs in an open syllable, and so does the phoneme / o / in English.

In line with the above characteristics of phonemes / o / and / o /, the English / o / is spelt with most vowel letters that make the 20 students of this study get big problems when speaking and reading English. Gimson (1987) states that the English / o / is spelt with most vowel letters, such as:

-o- / cord, horse, born, sword /, -aw- / saw, lawn, jaw /, -ou- / bought, ought /, a- / -a- / all, talk, salt, water, quart /, -ore- /before, more, etc./, -oo- / door, floar, etc./, -our- / court, four, etc./.

In conclusion, the sound of / $\mathrm{o} /$ in English also makes the 20 students of this study in a great problem to pronounce the acceptable R.P. English words possessing the sound of / o / because the spelling of this / o / is very distinguished from its pronunciation. Accordingly, the aforementioned students are inclined to exert / o / rather tha / o /. To know its differences, the following are phonemic oppositions and phonetic features as follows.

$\begin{array}{lll} & & \text { PHONEMIC OPPOSITIONS } \\ & \text { ENGLISH } & \text { BAHASA INDONESIA } \\ \text { Initial } & \text { : 'all' [ol] } & \text { 'obat' }[\text { obat }]=\text { medicine } \\ \text { Medial } & \text { : 'board' [bo:d] } & \text { 'sofa' }[\text { sofa }]=\text { bed } \\ \text { Final } & \text { : 'floor' [fo:] } & \text { 'romo' }[\text { romo }]=\text { priest }\end{array}$

\section{PHONETIC FEATURES}

\section{ENGLISH}

Back :

Mid

Rounded :

\section{BAHASA INDONESIA}

+
+
+

After presenting all consonant and vowel phonemes, the researcher of this study displays the phonotactics of the English and Indonesian consonants and vowels respectively.

\section{CONSONANT PHONEMES}

$\mathrm{p}$

b
INITIAL POSITION ENG. INDO. yes yes yes yes

\section{WORDS} MEDIAL POSITION FINAL POSITION ENG. INDO. ENG. INDO. yes yes yes yes yes yes yes no 


\begin{tabular}{|c|c|c|c|c|c|c|}
\hline $\mathrm{t}$ & yes & yes & yes & yes & yes & yes \\
\hline $\mathrm{d}$ & yes & yes & yes & yes & yes & no \\
\hline $\mathrm{k}$ & yes & Yes & yes & yes & yes & yes \\
\hline $\mathrm{g}$ & yes & yes & yes & yes & yes & no \\
\hline $\mathrm{f}$ & yes & yes & yes & yes & yes & yes \\
\hline V & yes & no & yes & no & yes & no \\
\hline$\theta$ & yes & no & yes & no & yes & no \\
\hline ð & yes & no & yes & no & yes & no \\
\hline $\mathrm{s}$ & yes & yes & yes & yes & yes & yes \\
\hline Z & yes & yes & yes & yes & yes & no \\
\hline $\int$ & yes & yes & yes & yes & yes & no \\
\hline 3 & rare & yes & yes & no & rare & no \\
\hline $\mathrm{h}$ & yes & yes & yes & yes & no & yes \\
\hline$t \int$ & yes & yes & yes & yes & yes & no \\
\hline db & yes & yes & yes & yes & yes & no \\
\hline $\mathrm{m}$ & yes & yes & yes & yes & yes & yes \\
\hline $\mathrm{n}$ & yes & yes & yes & yes & yes & yes \\
\hline$\eta$ & no & yes & yes & yes & yes & yes \\
\hline 1 & yes & yes & yes & yes & yes & yes \\
\hline $\mathrm{r}$ & yes & yes & yes & yes & no & yes \\
\hline $\mathrm{j}$ & yes & yes & yes & yes & no & no \\
\hline $\mathrm{W}$ & yes & yes & yes & yes & no & no \\
\hline
\end{tabular}

\section{VOWEL}

\section{PHONEMES}

$\mathrm{i}$
$\mathrm{I}$
$\mathrm{u}$
$\mathrm{U}$
$\mathcal{E}$
$\mathrm{x}$
$\partial$
$\mathrm{e}$
3
$\mathrm{a}$
$\Lambda$

4

\section{INITIAL POSITION} ENG.

yes

yes

rare

rare

yes

yes

yes

yes

yes

yes

yes

\section{INDO.}

yes

yes

yes

yes

yes

no

yes

yes

no

yes

no

\section{WORDS}

MEDIAL POSITION FINAL POSITION

ENG.

INDO.

ENG.

INDO.

yes

yes

yes

yes

yes

yes

yes

yes

yes

yes

no

yes

yes

no

yes

yes

yes

yes

yes

yes

yes

yes

yes

yes

yes

yes

yes

yes

yes

no

yes

no

yes

no 
yes

yes

yes yes

yes

yes no

yes

yes no

yes

yes

\section{Conclusion}

As already analyzed on the previous pages about the English and Indonesian phonological systems, the findings show us clearly that the phonological systems of both languages (L $2=$ English and L 1 = Bahasa Indonesia) have some similarities and discrepancies in terms of phonemic oppositions and phonetic features. The differences, of course, put learners of L 1 in much difficult in learning L 2, particularly in learning sound systems since L 1 has its own sound systems that are different from any other languages, and so does L 2 .

Broadly speaking, some groups of English sound systems should be paid much attention carefully in teaching pronunciations since they make learners of L 1 in a big difficulty in pronouncing English words. The first group is that the group of sounds that do not exist in

Bahasa Indonesia sound system, for examples: / æ, $\Lambda, 3, v, \theta, \partial /$. The second group is that sounds that exist in L 1 and L 2 but they have different phonetic features, such as: 1) Phonetic features: / b. d, g, z, s, t $t, d z /$ do not exist in the final positions of the word of Bahasa Indonesia, 2) Phonemic features: / p, t, k / are never aspirated in Indonesian words wherever they occur, 3) Phonemic feature: / $\mathrm{r} /$ is never pronounced clearly in English but in Bahasa Indonesia this / $\mathrm{r} /$ is always articulated clearly wherever it occurs in the words. The third group is that the spelling of English words. For examples: / s / is sometimes pronounced as / $\mathrm{z}$ / in English, and / a / is also sometimes pronounced as / æ, ə, e /. As a result, the L 2 learners fail to produce English words fluently and accurately.

\section{References}

Anderson, John M, \& Ewen, Colin J. (1987). Principles of dependency phonology. Cambridge: Cambridge University Press.

Bailey, Todd M., \& Hahn, Ulrike. (2001). Determinants of word likeness: Phonotactics or lexical neighborhoods? Journal of Memory and Language, 44, 568-591. Retrieved, March, 2006.

Bialystok, E. (2001). Bilingualism in Development: Language, Literacy and Cognition. Cambridge, England: Cambridge University Press.

Barlow. (2003). Phonological change and the representation of consonant clusters in Spanish. A Case Study. San Diego State University.

Brown, D. (2000). Principles of Language Learning and Teaching (4 ${ }^{\text {th }}$ Ed.). London: Longman.

Clements, G. N. (2005). The role of features in phonological inventories. In E. Raimy, \& C. E. Cairns (Eds.), Contemporary views on architecture and representations in phonological 
theory (pp. 19-68). Cambridge, MA: MIT Press. . Retrieved, April, 2006.

Dardjowidjojo, E. (1978). Sentence Patterns of Indonesian. The University Press of Hawaii.

Ellis, R. (2004). The study of second language acquisition. Oxford: Oxford University Press.

Gimson, A. G. (1980). An Introduction to the Pronunciation of English ( ${ }^{\text {rd }}$ Ed.) Edward Arnold Pty. Ltd., Australia.

Goldsmith, John A. (ed.). (1995). The handbook of phonological theory. Cambridge, Mass. \& Oxford: Blackwell.

Goldsmith, J., \& Xanthos, A. (2006). Learning phonological categories. Language, 85(1), 4-38. Retrieved, April, 2006

Kecskes, I., \& T. Papp. (2000). Foreign Language and Mother Tongue. Mahwah, NJ: Lawrence Erlbaum.

Kelly, G. (2000). How to teach pronunciation. London: Pearson Education.

Ladefoged, P. (2000). A course in phonetics. New York: Harcourt, Brace Jovanovich.

McDonald, R. R. (1976). Indonesian Reference Grammar. George Town University.

McKay, S. (2002). Teaching English as an international language. Oxford: Oxford University Press.

Nunan, D. (2001). Second language teaching and learning. Boston: Heinle \& Heinle Publishers.

Prince, Alan, \& Bruce Tesar. (2004). Learning phonotactic distributions. In 291Rene Kager, Joe Pater, \& Wim Zonneveld (eds.), Fixing priorities: constraints in phonological acquisition, 245 -. Cambridge: Cambridge University Press.

Roach, P. (2000). English phonetics and phonology. Cambridge: Cambridge University Press. Soebardi, S. (1873). Learn Bahasa Indonesia. Books 1 \& 2, Kanisius Bhratara, Indonesia.

Storkel, Holly L. (2003). Learning new words II: Phonotactic probability in verb learning. Journal of Speech, Language, and Hearing Research, 46, 1312-1323. Retrieved, January, 2007

Yule, G. (2006). The study of language. Cambridge: Cambridge University Press.

\section{Copyright Disclaimer}

Copyright reserved by the author(s).

This article is an open-access article distributed under the terms and conditions of the Creative Commons Attribution license (http://creativecommons.org/licenses/by/3.0/). 